\title{
Mapping Miskitu subsistence land use change in Concejo Territorial Katainasta, Honduras
}

\author{
El mapeo de los cambios de usos de subsistencia de la tierra en \\ el Concejo Territorial Miskito, Katainasta, Honduras
}

\author{
Taylor A. Tappan \\ Peter H. Herlihy ${ }^{2}$ \\ University of Kansas, USA
}

\begin{abstract}
Understanding the large-scale spatial patterns of natural resource use in indigenous homelands is critical for guaranteeing indigenous peoples' ancestral land rights, designing effective conservation policies, and promoting good governance in Central America. However, few studies have mapped the diachronic distribution of indigenous communities' resource use in these areas. Here we present a case study describing the spatial functionality of the Concejo Territorial Katainasta (CTK)--the first indigenous territorial jurisdiction in Honduras to receive an intercommunity land title. Two participatory research mapping (PRM) studies--the first in 1992 and the second in 2014-15--mapped the spatial patterns of Miskitu subsistence activities in CTK. The results were subsequently converted into a geographic information system (GIS) that allowed for spatial and temporal comparisons of Miskitu subsistence livelihoods in CTK before and after the titling process. Here we focus on the spatial parameters of three Miskitu subsistence livelihoods: agriculture, hunting and fishing. Analysis of results suggests that 1) the 2014-15 subsistence use areas for Miskitu communities in CTK have not diverged dramatically from those of the 1992 study, and 2) the new legal boundaries of CTK adequately encompass the subsistence use areas of its constituent communities and recognize the historical overlaps in Miskitu resource use and tenure patterns.
\end{abstract}

Keywords: Honduras, Miskitu, concejo territorial, indigenous, resource use

1 Taylor is a Ph.D. candidate in the Department of Geography and Atmospheric Science at the University of Kansas

2 Dr. Herlihy is a professor of geography in the Department of Geography and Atmospheric Science at the University of Kansas

Este artículo corresponde a la ponencia presentada en el 35th Conference of Latin American Geographers realizada en San José, Costa Rica del 20 al 22 de mayo del 2018 


\begin{abstract}
Resumen
Comprender los patrones espaciales a gran escala del uso de los recursos naturales en las tierras de origen indígenas es fundamental para garantizar los derechos ancestrales sobre la tierra de los pueblos indígenas, diseñar políticas de conservación eficaces y promover el buen gobierno en América Central. Sin embargo, pocos estudios han mapeado la distribución diacrónica del uso de los recursos de las comunidades indígenas en estas áreas. Aquí presentamos un estudio puntual que describe la funcionalidad espacial del Concejo Territorial Katainasta (CTK) - la primera jurisdicción territorial indígena en Honduras en recibir un título de tierra intercomunitario. Dos estudios de investigación cartográfica participativa (ICP o PRM por sus siglas en inglés) - el primero en 1992 y el segundo en 2014-15 - mapearon los patrones espaciales de las actividades de subsistencia de las comunidades miskitas en CTK. Los resultados se convirtieron posteriormente en un sistema de información geográfica (SIG) que permitió comparaciones espaciales y temporales de los medios de subsistencia miskitos en CTK antes y después del proceso de titulación. Aquí nos enfocamos en los parámetros espaciales de tres medios de subsistencia miskita: agricultura, caza y pesca. El análisis de los resultados sugiere que 1) las áreas de uso de subsistencia en 2014-15 para comunidades miskitas en CTK no divergieron dramáticamente de las del estudio de 1992, y 2) los nuevos límites legales de CTK abarcan adecuadamente las áreas de uso de subsistencia de sus comunidades constituyentes y reconocen las superposiciones históricas en el uso de los recursos y los patrones de tenencia del pueblo miskito.
\end{abstract}

Palabras clave: Honduras, Miskito, concejo territorial, indígena, manejo de recursos naturales

\title{
Introduction
}

In 2012 Concejo Territorial Katainasta (CTK) became the first of twelve Miskitu concejos territoriales (Figure 1) to receive intercommunity land title from Honduras's National Agrarian Institute (INA). The concejos territoriales (territorial councils or CTs) represent a spatial reconfiguration of regional federations established by Miskitu community leaders during the 1990s. The federations were based in part on spatial delimitations of shared multi-community "subsistence zones" of marine and terrestrial resource uses. The new CTs emerged from these groupings, signifying an unprecedented devolution of land and political autonomy to Miskitu communities (Alvarez et al., 2017; Galeana \& Pantoja, 2013; Herlihy \& Tappan, 2018). 
Taylor A. Tappan, Peter H. Herlihy. Mapping Miskitu subsistence land use change in Concejo Territorial Katainasta, Honduras

Figure1. Concejos Territoriales in the Honduran Muskitia

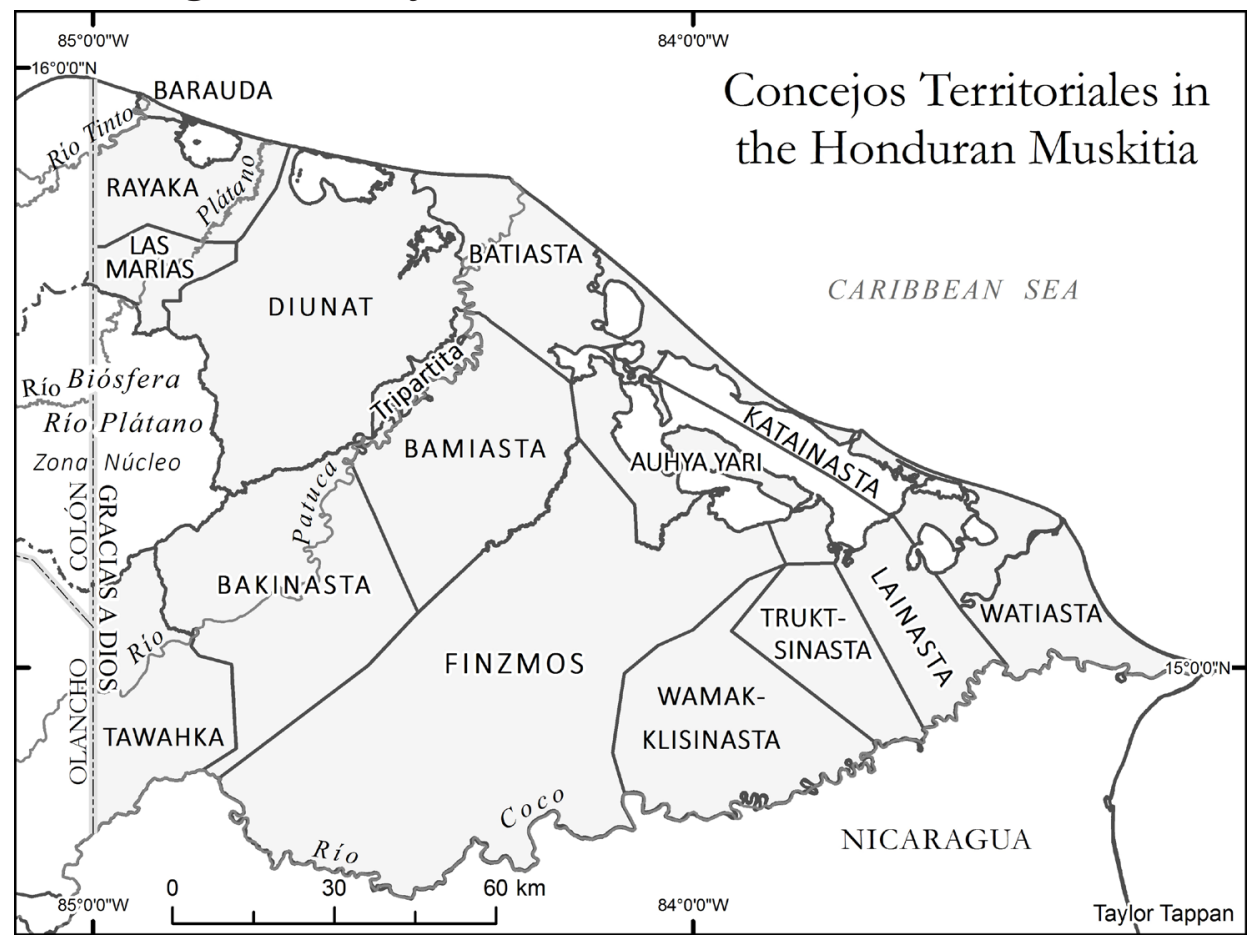

The Miskitu subsistence zones-so-called "functional habitats"included extensive land, forest, and resource uses shared by multiple communities (Herlihy \& Leake, 1997) that are accommodated within the new CT delimitations to greater or lesser degrees (Herlihy \& Tappan, 2018). CT boundaries are permeable, reflecting customary tenure overlaps between two or more Miskitu communities. This permeability maintains intact the ancestral structure of overlapping Miskitu subsistence livelihoods in which community members often travel many kilometers to their forest-fallow agriculture sites or fishing and hunting grounds.

Katainasta (CTK) is situated on a narrow isthmus between the Caribbean Sea and inland lagoons where thirty-nine Miskitu communities are officially recognized in its title (INA, 2012). The titled area includes $550 \mathrm{~km}^{2}$ across the isthmus, bounded in the northwest by Barra Tabakunta and in the southeast by the Río Kruta. An open maritime passageway links the Caribbean Sea and inland Caratasca Lagoon. The coastal lowlands are 
covered by lagoons and swamps of great importance for Miskitu fishing and hunting. The subsistence use area of CTK nearly triples in size when one considers the importance of Caratasca Lagoon and other inland water bodies for Miskitu fishermen, but Honduran law does not allow for the titling of water bodies.

Figure 2. Katainasta Settlements and Overlapping Land Use, 2015

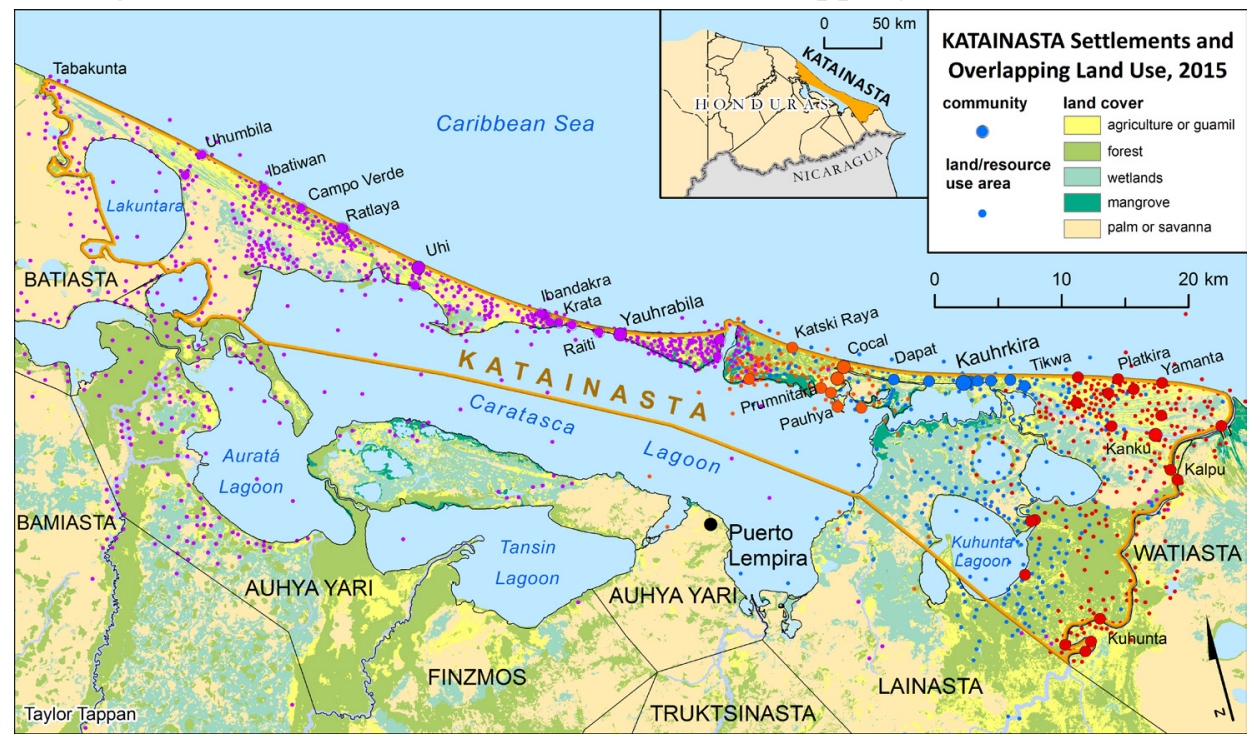

Fishing and forest-fallow agriculture are the most important food-producing activities for CTK communities. Miskitu agriculturalists periodically travel klaura (upriver) into neighboring CTs Auhya Yari, Finzmos, Lainasta, and Watiasta to cultivate rice, beans, maize, and manioc along the banks of the Río Kruta or Río Warunta. After cultivation, the fields are managed as secondary regrowth in a stage called guamil, allowing for soil regeneration and plant succession (Herlihy, 2001; Cochran, 2008). Agricultural plots in the guamil stage attract game animals like white-tailed deer, green iguana, and white-lipped peccary that are prized in the Miskitu diet (Dunn \& Smith, 2011: 93). This pattern of overlapping forest-fallow agriculture and managed guamil is a hallmark of Miskitu land use and is demonstrated in Figure 2, where spatial clusters of communities and their resource use sites have been assigned disparate colors to show their 
overlapping nature. Tenure over a given plot is based on usufruct rights, where both private and communal lands are recognized by Miskitu communities (Herlihy \& Tappan, 2018).

\section{Participatory Research Mapping (PRM)}

This study offers a comparative spatial analysis of Miskitu subsistence resource use through PRM field work in CTK communities and their surroundings in 1992 and again in 2014-2015. It builds upon the baseline research of geographers Herlihy and Leake who designed the first PRM experience in Latin America to study the land use patterns of Miskitu communities in the Honduran Muskitia (Herlihy \& Leake, 1997). Through PRM, local investigators, elected by their communities on merit of their strong leadership qualities, were trained to draw cognitive sketch maps of their communities and the lands and waters surrounding them, to apply land use questionnaires in community assemblies, and to record toponyms (place names) of important resource use sites. The iterative PRM process of training workshops and field work allowed the geographers to aid participants in converting Miskitu cognitive spatial knowledge into consensual maps and then into standard cartographic forms (Herlihy \& Knapp, 2003). Project results built upon existing 1:50,000 cartographic sheets and provided the most accurate placement of Miskitu communities and the only assessment to date of their subsistence zones.

More than 20 years later, Miskitu leadership (MASTA) invited Herlihy and the University of Kansas (KU) Centroamérica Indigena Project to lead a second PRM in CTK to train "local geographers" and develop new cartographic information for resource use management in CTK. Results of the subsequent PRM project also lend a window on how subsistence land use has changed in CTK over the last two decades, which is the focus of this essay.

An international consortium of university, indigenous, government, and NGO collaborators, led by researchers from the University of Kansas and MASTA (the Miskitu umbrella political federation), pooled human and economic capital to map CTK in 2014-15. Community leaders in CTK were entrusted to select local community representatives who would be trained as local geographers in the PRM process. A team of 13 participated in a series of workshops organized and led by KU professors and graduate students with Miskitu undergraduate students from Honduras's 
Universidad Pedagógica Nacional Francisco Morazán (UPNFM). The team worked closely with MASTA leaders to impart the PRM methodology to the local Miskitu participants, who learned how to read and interpret topographic sheets, capture waypoints using a global positioning systems (GPS) unit, draw cognitive sketch maps, and apply land and resource use questionnaires in community assemblies.

In the succeeding months following the first training workshop, local Miskitu investigators worked in two teams, traveling throughout CTK and organizing public assemblies in each community. They completed resource use questionnaires while recording the toponyms of all relevant resource use areas in each of CTK's 39 communities. The toponyms from these community questionnaires were then located on simple cognitive sketch maps drawn by the local investigators in collaboration with community members and ancianos (community elders) in the assemblies.

Thus began the iterative process critical to PRM methodology: the review and community validation of the maps, toponyms, and resource use information. The local Miskitu investigators returned with the community resource use questionnaires, a cognitive sketch map for every community, and a regional locator sketch map with the location of all the communities surveyed by each team. Geographers from KU worked with the local investigators to plot the CTK toponyms and land use points onto 1:50,000-scale base maps created by the KU geographers. Following the workshop, the maps were redrawn to combine the cartographic and indigenous knowledge onto new 1:50,000-scale sheets and then scanned and returned to the local investigators in CTK. Once again, the local investigators organized assemblies in each CTK community to review the information. This process effectively allowed the transformation the cognitive sketch maps into consensual maps, which were revisited in a third and fourth workshop.

While the local investigators organized community assemblies in CTK to review the cartographic information they had collected, the KU geographers scanned and georeferenced copies of the same maps and began constructing the GIS-based final maps using ArcGIS versión 10.2 software. New maps were printed and distributed to the local investigators after each workshop to complete an iterative process of revision and community validation. After four workshops and three sessions of field work by the local investigators, the KU geographers produced the final map of 
Taylor A. Tappan, Peter H. Herlihy. Mapping Miskitu subsistence land use change in Concejo Territorial Katainasta, Honduras

CTK. The map was published on the Centroamérica Indigena website (www.prmapping.ku.edu). A ceremony and press event were held at the Universidad Pedagógica Nacional Francisco Morazán (UPNFM) in Tegucigalpa in June 2015 to submit the final map of CTK to MASTA and the junta directiva (governing board) of CTK.

\section{Spatial Analysis}

Figure 3. Land/Resource Use Sites of Katainasta Communities, 1992

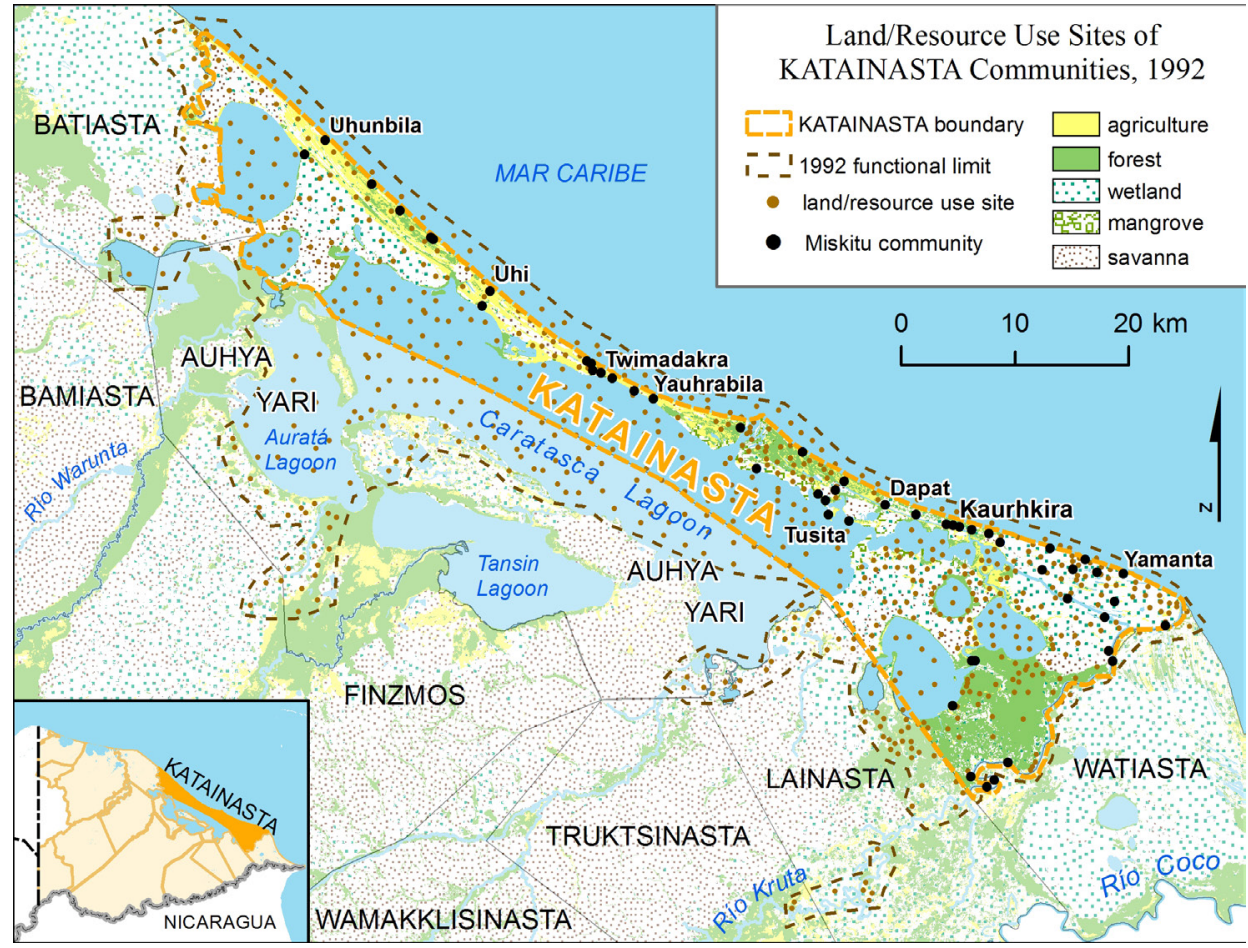


Figure 4. Land/Resource Use Sites of Katainasta Communities, 2015

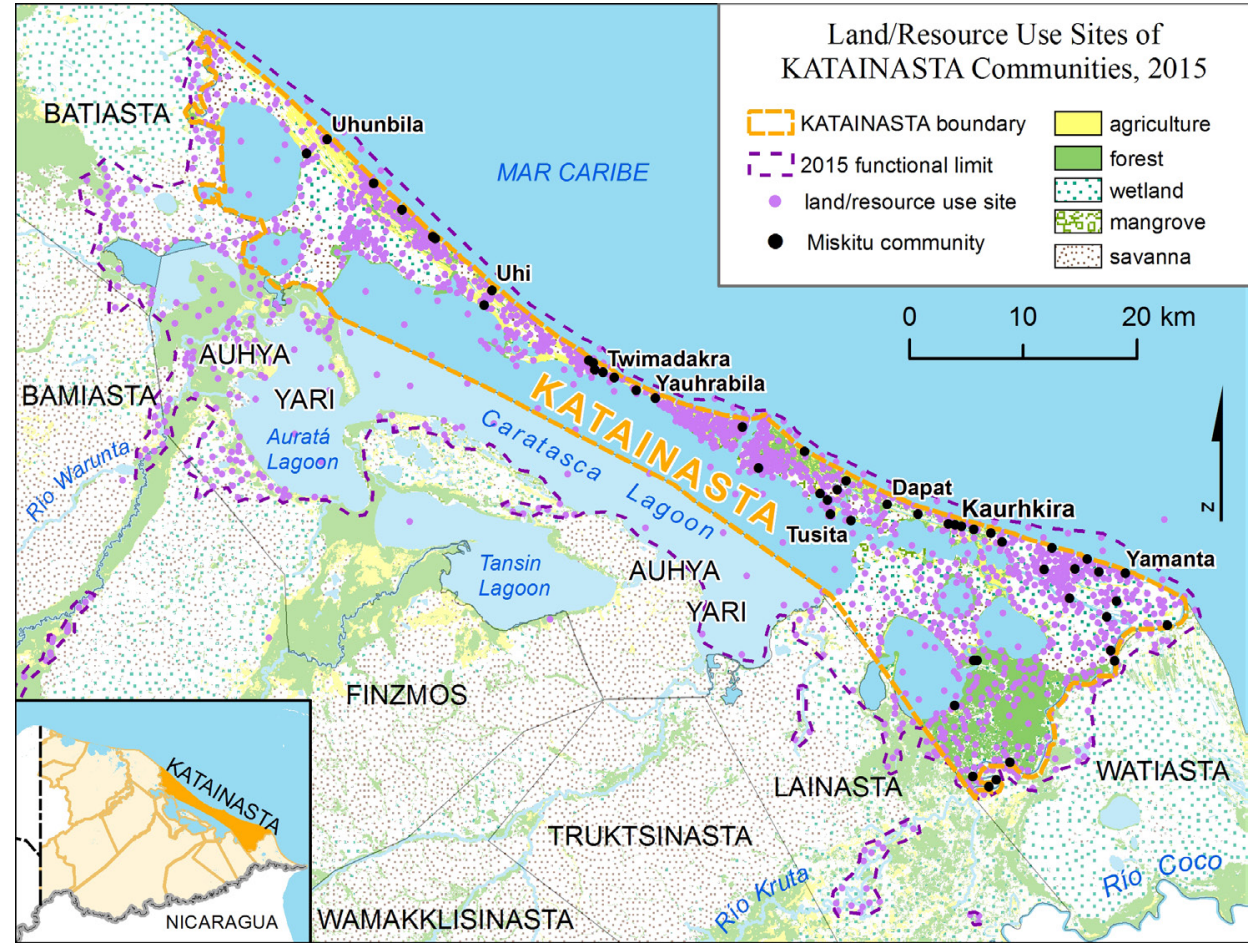

The spatial analysis for this paper was conducted in 2015 after the final map production of CTK. ArcGIS version 10.2 software was used to display Miskitu land and resource use points for both the 1992 and 20142015 PRM studies. These two distributions were compared to the legal limits of CTK to determine whether the limits adequately encompass the functional land and resource region occupied by Miskitu communities within CTK (Figures 3 and 4). A statistical analysis of the 2014-2015 points for agriculture, fishing, and hunting was also conducted to determine the approximate minimum, maximum, mean, and standard deviation for distances traveled by members from any given community to their land and resource use sites.

This computation was done using the "Near" tool in ArcGIS software that calculates the Euclidean (straight line) distance between selected input features (e.g., land use points) and the nearest feature in another layer or feature class (e.g., Miskitu communities in CTK). Resource use 
sites (agriculture, fishing, and hunting) from the 2014-2015 PRM work were selected for every individual community in CTK by querying the attribute points numerically coded to each of their corresponding communities (e.g., "A ${ }_{20} "=$ agriculture from community $\# 20$; " $\mathrm{P}_{13}$ " = pesca (fishing) from community \#13). Euclidean (straight line) distance was then calculated in meters from the selected resource use points back to each community center. The distances in meters are approximate because land and resource use areas were not located by GPS; instead, these sites were noted on sketch maps drawn by the local Miskitu investigators with respect to important geographic features and associated toponyms. Representing exact locations of subsistence land or resource use is a challenge for cartographers given their fluid, fluctuating dimensions. In this study simple points (which have no spatial dimensions at all, mathematically speaking) were used as markers for Miskitu land and resource use, but a user of our maps should interpret point locations as approximate indicators for land and resource use, thus representing an area around a given point. Fishing and hunting locations will vary considerably, perhaps by as much as a kilometer or more, given the mobile nature of these activities, while forest-fallow agricultural points are likely more static along lagoons and rivers.

\section{Results}

Examining the spatial patterns of subsistence activities provides a glimpse into the complex ecologies of the Miskitu cultural landscape. At a glance, the functional limits of the 1992 and 2014-2015 studies, when superimposed over one another, don't appear to vary greatly over time (Figure 5). We notice spatial similarities in the functional use limits even when examining an isolated cluster of points representing areas of agriculture outside the limits of CTK along the Río Kruta, accessed by communities from the eastern margins of CTK. The presence of this cluster on both maps demonstrates the historical overlapping nature of Miskitu land use patterns. However, CTK communities working these agricultural kiamps in 1992 must now cross legal boundaries into neighboring CTs Lainasta and Truktsinasta after new collective land titles have redrawn the political and administrative landscapes of the Muskitia region.

One difference in the functional use areas between the two maps can be found along the Río Warunta. Local investigators from the 2014-2015 
located a cluster of agricultural and hunting points in this location that hadn't previously been tallied by investigators in 1992. This variation could reflect an expansion of resource use by CTK communities into this area. The change may also indicate population growth in CTK, by which CTK communities have expanded well beyond the new legal boundaries of their CT in search of fertile soil and game animals. Of the $32 \mathrm{CTK}$ communities surveyed by local investigators during the 2014-2015 PRM process, 12 reported traveling $20 \mathrm{~km}$ or farther to reach upriver agricultural lands, while 16 communities reported traveling more than $20 \mathrm{~km}$ in search of game animals. These results are consistent with the research of Smith \& Dunn (2011) who documented how Miskitu agriculturalists often combine work on their riparian agricultural plots with hunting excursions.

Figure 5. Functional Subsistence Zones for Katainasta Communities, 1992 and 2015

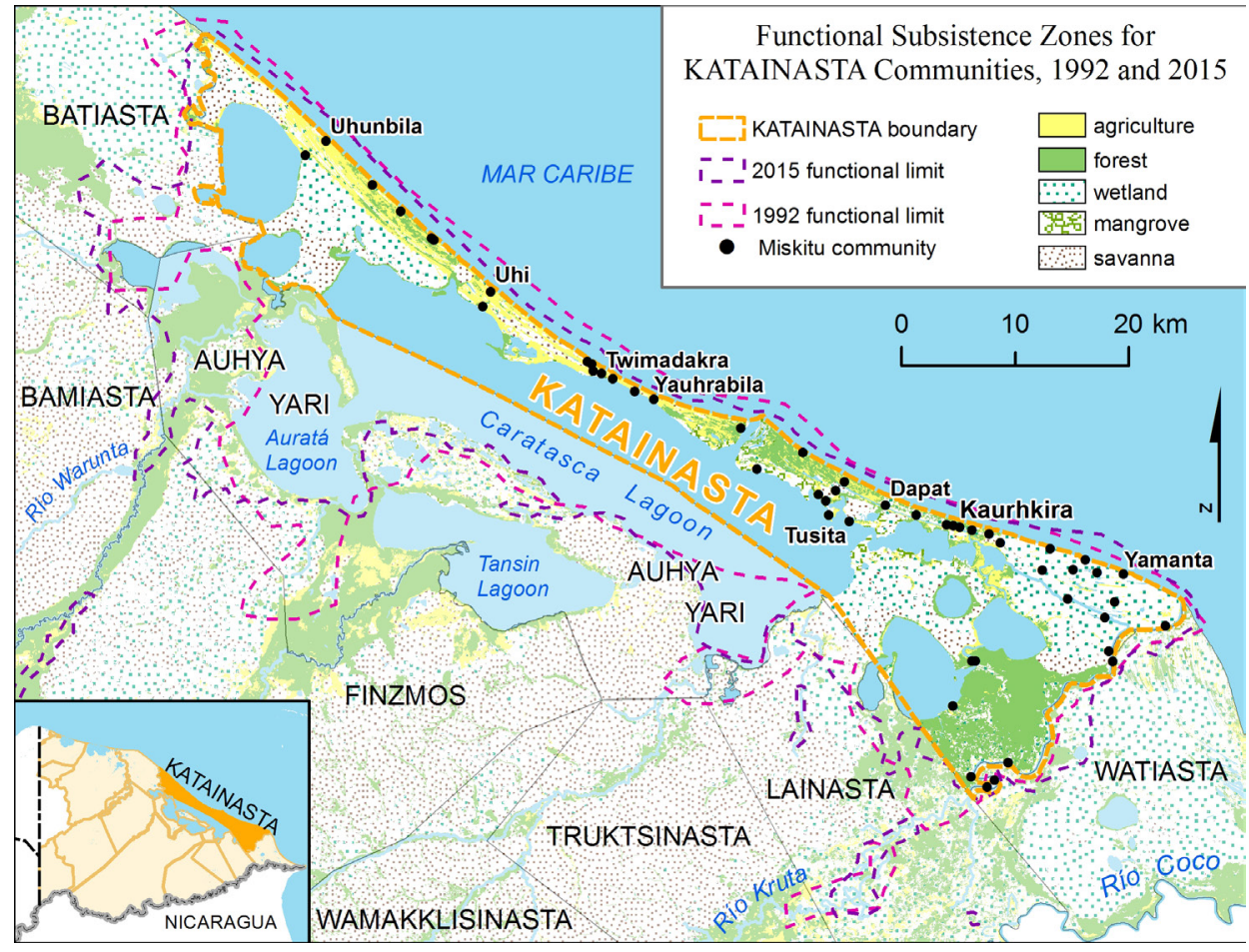

618 Revista Geográfica de América Central No 61E (3) Especial CLAG Este artículo está bajo una licencia e-ISSN 2215-2563 • Julio-diciembre 2018 • pp. 609-622 Atribución/Reconocimiento-NoC Doi: http://dx.doi.org/10.15359/rgac.61-3.33

CompartirIgual 4.0 Internacional 
Another notable discrepancy between the 1992 and 2015-15 maps (Figures 3 and 4) is the varying patterns of concentrated and dispersed land use points. This is perhaps more reflective of a cartographic inconsistency than one that represents changes in land use by CTK communities. For instance, the 1992 map located points at regular intervals across Caratasca Lagoon to demonstrate its importance for CTK fishermen. These 1992 points were not GPS-located waypoints, and the majority are not tied to a particular fixed toponym (other than Caratasca Lagoon); however, they show that fishermen from CTK communities harvest their catch from all corners of this vast lagoon, even in waters extending into CT Auhya Yari. Likewise, we notice 2014-2015 CTK fishing points along the shores of Caratasca Lagoon and the adjacent Auratá Lagoon, but without the rather uniform distribution across the center of the lagoons. In the case of the 2014-2015 PRM study, the recorded distances that CTK communities are willing to travel in search of fish often exceed $20 \mathrm{~km}$, with 14 communities having located fishing points beyond this threshold. These data suggest that CTK fishermen continue to migrate long distances in search of their catch, as they did nearly 25 years ago.

\section{Discussion and Concluding Remarks}

The findings of original PRM research and this GIS-based study confirm that CTK communities continue to use extensive areas of land and water for basic subsistence. Miskitu local investigators first worked to demonstrate their communities' territoriality on standard maps in the 1992 PRM. Nearly twenty-five years later, a second PRM study of land and resource use further validated the functional territorial limits of KATAINASTA communities as identified by "local geographers." Results demonstrate that members from a given community travel as far as 30 or $40 \mathrm{~km}$ to hunt, fish, and work riparian agricultural fallows. Such mobility inevitably carries Miskitu hunters, fishermen, and agriculturalists beyond the new legal limits of CTK and into neighboring territories. However, ancestral Miskitu culture draws upon notions of reciprocity and allows for overlapping land and resource use among communities. In this vein, the functional resource use areas of CTK communities do not seem to have changed significantly between 1992 and 2014-2015, but the creation of the twelve Miskitu CTs does complicate the geopolitical 
landscape of eastern Honduras by imposing a new set of boundaries that partition community resource use areas.

Indeed, each CT, governed by its resident communities, must now develop an ordenamiento territorial, or governance structure, for managing its territories and natural resources. Will individual CT governments continue to recognize reciprocal land management and resource exploitation? Will the contiguous set of new CT boundaries remain permeable across Muskitia, or will their ultimate functionality keep people in place? Can new CT governance structures coordinate with existing municipal governments to provide information and services to Miskitu communities without destroying the ecology of the region? These concerns have not yet been resolved, but they may determine the success of the CTs and the conservation of their lands and resources. Additional cartographic information produced through participatory approaches may be necessary for Miskitu leaders to demonstrate their ancestral rights to land and resources, but for today, our results suggest that the newly-delimited CTK boundaries adequately encompass the subsistence use areas of constituent communities and their overlapping use areas with neighboring CTs.

\section{Footnotes}

1. Barauda, Las Marías, and Tawahka (representing Garífuna, Pech, and Tawahka indigenous communities, respectively) are seeking but have not yet received intercommunity land titles at the time of this paper.

2. Two of the local investigators from the 1992 mapping (Gilberto Maibeth and Duval Haylock) returned in 2014-15 to participate as "local geographers" in the new 2014-15 PRM. At this time they were also serving as President and Vice President of Concejo Territorial Katainasta, respectively. The complete list of local participants from the 1992 PRM includes Olegario López, Ricardo Ramírez, Quintín Castro, Máximo Chow, Wilmer Waldemar, Hernan Martínez, Moisés Alemán, Edimor Wood M., Tomás Rivas, Dionisio Cruz, Gilberto Maibeth, Daniel Castellón, Simón Greham P., Javier Rimundo G., Duval Haylock, Eduardo Padilla, Electerio Pineda K., Daniel Kiath, Cecilio Tatallón, Paulino Bossen, Sinito Waylan, and Manuel Martínez. The "Local Geographers" in the 2014-15 PRM were Dina Larissa Bendles, Jairo Bendles, Helen Yajaira Calderón, Duval Haylock, 
Bessy Melado Wood, Mirna Melado Wood, Melbioleta Melendrez M., Delvar Méndez Bonilla, José Chacón Padilla V., Guillermo Rosales, and Gilberto Maibeth.

3. This research was part of the KU-American Geographical Society (AGS) Bowman Expedition called Centroamérica Indígena, funded in part by a Minerva Initiative Grant for University-Led Research from the Office of the Secretary of the United States Department of Defense, supported by the U.S. Army Research Laboratory and the U.S. Army Research Office under Contract/Grant W911NF1310281.

\section{References}

Álvarez, R., Pantoja, E., Granados, G. \& Paz, A. (2017). “Strengthening Indigenous Peoples Land Rights in Honduras: The Miskitu People's Experience of Collective Land Titling, Lessons Learned, and Main Challenges for the Future." Paper presented at the 2017 World Bank Conference on Land and Poverty, Washington, D.C.

Centroamérica Indígena Project (2018). Land Rights and Stability in Indigenous Societies of Central America. A five-year geographic research project of the University of Kansas and the American Geographical Society. Funded in part by a Minerva Initiative Grant for UniversityLed Research from the Office of the Secretary of the United States Department of Defense, supported by the U.S. Army Research Laboratory and the U.S. Army Research Office under Contract/Grant W911NF1310281. Lawrence, KS, 2013-2018.

Cochran, D. M. (2008). Who Will Work the Land? National Integration, Cash Economies, and the Future of Shifting Cultivation in the Honduran Mosquitia. Journal of Latin American Geography, 7(1), 57-84.

Dunn, M. A. \& Smith, D. A. (2011). The Spatial Patterns of Miskitu Hunting in Northeastern Honduras: Lessons for Wildlife Management in Tropical Forests. Journal of Latin American Geography, 10(1), 85-108.

Galeana, F. \& Pantoja, E. (2013). Strengthening Indigenous Peoples' Land Tenure Governance: The Case of the Miskito People in Honduras. Paper presented at the Annual World Bank Conference on Land and Poverty, Washington, D.C. 
Herlihy, P. H. (2001). Indigenous and Ladino Peoples of the Río Plátano Biosphere Reserve, Honduras. In S. C. Stonich (Ed.), Endangered Peoples of Latin America: Struggles to Survive and Thrive (pp. 100120). Westport, CT: Greenwood Press.

Herlihy, P. H. \& Knapp, G. (2003). Maps of, by, and for the Peoples of Latin America. Human Organization, 62(4), 303-314.

Herlihy, P. H. \& Leake, A. P. (1997). Participatory Research Mapping of Indigenous Lands in the Honduran Mosquitia. In A. R. Pebley \& L. Rosero-Bixby (Eds.), Demographic Diversity and Change in the Central American Isthmus (pp. 707-736). Santa Monica, CA: Rand Books.

Herlihy, P. H. \& Tappan, T. A. (July 2018). Recognizing Indigenous Miskitu Territory in Honduras. Geographical Review, 108(3),1-20 doi. http://dx.doi.org/10.1111/gere.12309

Instituto Nacional Agrario de Honduras (INA). (2012). Título Definitivo de Propiedad Intercomunitario en Domino Pleno (Concejo Territorial KATAINASTA). In Registration No.2621. 